\title{
MEMAHAMI TEORI-TEORI ETIKA: \\ CAKRAWALA DAN PANDANGAN
}

\author{
Oleh: Mohammad Maiwan*
}

\begin{abstract}
This study discusses ethical theory. The method used is descriptive analysis with a qualitative approach. Ethics affirms the principles of behavior that must be carried out by individuals to adjust to the good they receive. We know several ethical theories, namely: First, sosial morality theory. This theory states that society is the most authorized in describing sosial truth. Something that is considered good or bad, appropriate or inappropriate, moral or immoral if it is in harmony with values, norms, and law in society. Second, personality virtue theory. This theory argues that efforts to develop morals must lead to the formation of noble and best character. Problems that are more emphasized are individual or human dimensions, and not actions. Third, teleological theory. This theory states that good or bad actions depends on the goals achieved. An action that means good, but does not produce anything meaningful, according to this theory is not called good. The theory emphasizes the impact of the actions. Teleological theory divided into two school of thought, namely; utilitarianism and egoism. Fourth, deontology theory. This theory confirms that good or bad behavior is not assessed based on its impact, but because of obligation. The behavior is never good because the results are good, but only because they are needed. So determining value is a good, right, and moral are from characteristic actions.
\end{abstract}

Keywords: Ethics, morals, theory.

\section{Pendahuluan}

etika amat penting dilakukan mengingat dalam setiap sepak terjang kehidupan kita senantiasa berkaitan dengan individu dan kelompok lain. Perbedaan-perbedaan dalam sikap, nilai, dan pandangan membawa implikasi pada hubungan sosial yang lebih luas. Dewasa ini, dalam kehidupan manusia modern yang berkembang pesat, aspek-aspek yang menyangkut dimensi etika seringkali terabaikan dalam praktek kehidupan nyata. Meskipun orang menggebugebu berbicara tentang etika moral di sepanjang segi-segi kehidupan, baik ekonomi, politik, sosial, pendidikan, budaya, teknologi, dan lain-lain, tetapi hakikatnya praktek kehidupan kita belum sepenuhnya sejajar dengan etika moral ideal yang diharapkan.

\footnotetext{
* Dosen Program Studi Pendidikan Pancasila dan Kewarganegaraan Fakultas Ilmu Sosial Universitas Negeri
} Jakarta 
Adanya pergeseran orientasi dan cara pandang manusia dalam memecahkan persoalan kehidupan menyebabkan wujud perubahan nilainilai serta standar etika yang berlaku. Pada kenyataannya, kita mengetahui bahwa eksistensi individu bukanlah semata-mata produk dirinya, tetapi juga lingkungan sosialnya. Manusia hakikatnya berdimensi monopluralis, dalam arti selain merepresentasikan jati dirinya sebagai individu, sekaligus bagian dari lingkungan sosialnya, sehingga memiliki tingkat kesadaran yang berbeda-beda tentang nilai hidup. Selain itu, sebagai subyek atau pelaku, agen, penilai, penyebar, bahkan pengkritik moral, manusia sesungguhnya juga adalah obyek moral itu sendiri, baik itu sebagai konsekwensi interrelasi dengan sesama maupun tatanan sistem kehidupan yang hadir (Palese 2013: 366).

Harapan akan kehidupan yang damai dan membahagiakan senantiasa bersandar pada nilai-nilai etika dan kemoralan. Kesadaran akan nilai-nilai tersebut perlu dipupuk secara terus menerus. Berdasarkan pandangan tersebut, kajian ini akan menumpukan perhatian pada pembahasan tentang teori-teori etika untuk memberikan landasan pemahaman yang baik, tentang bagaimana kita menilai berbagai fenomena yang ada serta bertindak sesuai dengan etika. Secara khusus, kajian ini lebih bersifat menggali perspektif-perspektif tentang teori etika serta relevansinya dengan persoalan kemanusiaan yang dihadapi hari ini.

\section{Konsep dan Makna Etika}

Istilah etika (ethice) berasal dari Bahasa Yunani yang berarti perilaku seseorang, adat istiadat (kebiasaan), perasaan batin, watak, serta kecenderungan hati, untuk melakukan suatu perbuatan. Selain itu, istilah etika juga dipahami sebagai kajian tentang tingkah laku manusia, tentang apa itu baik atau buruk, benar atau salah, sengaja atau tidak. Menurut pakar filsafat Mesir yang tersohor, Ahmad Amin (1983: 3), etika adalah ilmu yang menjelaskan arti baik dan buruk, menerangkan apa yang seharusnya dilakukan oleh manusia, menyatakan tujuan yang harus dituju oleh manusia di dalam perbuatan mereka dan menunjukkan jalan untuk melakukan apa yang 
seharusnya diperbuat. Sementara Hamzah Ya'qub (1983: menyatakan etika sebagai ilmu yang menyelidiki mana yang baik dan mana yang buruk dengan memperhatikan amal perbuatan manusia sejauh yang dapat diketahui oleh akal pikiran. M. Amin Abdullah (2002: 15) mengartikan etika sebagai ilmu yang mempelajari tentang baik dan buruk. Beliau selanjutnya menyatakan bahwa, etika berfungsi sebagai teori perbuatan baik dan buruk, yang praktiknya dapat dilakukan dalam disiplin filsafat.

Etika menegaskan prinsipprinsip perilaku yang perlu ditempuh individu agar bersesuaian dengan kebajikan yang diterima. Melalui etika individu dapat mengontrol seluruh sikap dan perbuatannya agar tidak bertentangan dengan orang lain. Etika sangat dipengaruhi pengalaman pribadi dan sosial seseorang serta tingkat perkembangan psikologisnya. Dengan demikian, penerapan prinsipprinsip etis juga merupakan refleksi dari kematangan pribadi seseorang. Dalam konteks yang lebih luas, perbuatan etis mengarahkan orang pada satu tanggungjawab tertentu untuk mewujudkan kebaikan dalam komunitas. Secara ilmiah, etika adalah suatu kajian ilmiah tentang perilaku manusia dalam masyarakat, yakni suatu bidang yang mendefenisikan perilaku manusia sebagai benar atau salah, baik atau buruk, patut atau tidak patut. Sedangkan dalam perspektif ajaran Islam, etika merujuk pada tingkah laku yang baik dan betul berdasarkan nilai-nilai Islam, yakni merujuk pada al-Qur'an dan al-Sunnah. Oleh karena itu, bagi kaum Muslim, di manapun juga rujukan terhadap kebaikan etis tidak dipisahkan dari patokan alQur'an dan al-Sunnah yang secara empirik mampu membentuk pribadi yang baik.

Dalam lingkup kehidupan sehari-hari, kita mengenal adanya berbagai macam pedoman etika atau kode etik, mulai dari etika organisasi, lembaga-lembaga pemerintah dan swasta, korporasi, sekolah, pesantren, serta profesi, yang menjadi pemandu bagi perilaku individu, atau kelompok dalam organisasi atau profesi pekerjaan. Dalam dunia kedokteran, pengacara, konsultan, insinyur, birokrasi, anggota parlemen, guru, kita mengenal adanya etika masingmasing bidang profesi tersebut. Etika 
organisasi ialah garis pedoman untuk menjalankan tugas seperti berpegang pada prinsip bersih, cakap, amanah, jujur, benar, ikhlas, bertanggungjawab dan adil. Etika profesi (professional ethics) ialah kode yang menggariskan apa-apa yang harus dibuat dan tidak harus dibuat oleh pelaksana profesi tersebut (Davis 2014: 2). Misalnya, etika Aparatur Sipil Negara (ASN), yang menggariskan prinsip-prinsip yang perlu dipegang teguh setiap ASN yang meliputi: Sikap jujur, tulus, netral, bertanggungjawab, komited, adil, terbuka, melayani, yang menjadi panduan dalam bekerja.

\section{Adalah} menjadi tanggungjawab setiap individu agar mematuhi prinsip-prinsip etika sesuai bidang kehidupan masing-masing. Dalam kaitan ini, konsep etika berkaitan erat dengan moral dan insan bermoral, yang bermaksud bahwa seseorang yang mempunyai perilaku etis dapat dianggap sebagai bermoral (Ljupco 2017: 86). Ada tiga aspek penting yang dapat dikemukakan di sini berkaitan dengan konsep etika, yakni: Isi, bentuk, serta dimensi etika. Aspek isi adalah berkaitan dengan peraturan dalam masyarakat yang perlu dipatuhi bersama. Adanya peraturan di dalam masyarakat sangat diperlukan karena peraturan tersebut dapat menjamin kenyamanan hidup bermasyarakat, prinsip dalam hubungan kemanusiaan lingkungan.

Tanpa peraturan, masyarakat manusia tidak dapat berfungsi secara efektif karena nilai-nilai individu akan bertentangan dengan nilai-nilai masyarakat memungkinkan seseorang itu kelihatan seenaknya, sombong, individualis, kurang ajar, sehingga boleh jadi merusak masyarakat. Kita bisa melihat hal ini dari beberapa insiden, misalnya: Adanya perilaku kebut-kebutan di jalan, begal motor, penyalahgunaan narkotika, korupsi, pencurian, perusakan lingkungan dan sebagainya, yang menunjukkan tidak dipatuhinya peraturan.

Dalam konteks Indonesia yang memiliki masyarakat beragam yang terdiri dari berbagai suku bangsa, asal daerah, lapisan sosial, serta keyakinan dan tradisi yang berbeda maka kepatuhan dan saling memahami nilai dan peraturan adalah sangat penting dalam menjaga kestabilan masyarakat. Kesadaran individu maupun kelompok dalam 
memahami perbedaan akan menjauhkan dari konflik nilai, prasangka, yang dapat menggugat kedamaian. Etika persamaan dan kebebasan misalnya perlu dipahami dengan matang dan dipraktekkan secara wajar mengikuti tata nilai yang berlaku. Kebebasan bukanlah sematamata bebas untuk melakukan semua tindakan, tetapi perlu memikirkan dampak yang diakibatkannya lebih jauh. Apa yang hari ini disebut sebagai kebebasan yang bertanggungjawab perlu dilihat dalam konteks ini.

\section{Beberapa Teori Moral}

\section{Teori Moralitas Sosial (Sosial}

\section{Morality Theory)}

Teori bersumber dari pemikiran Thomas Hobbes (15881679), Emile Durkheim (1858-1917) dan Max Weber (1864-1920). Teori ini menyatakan bahwa manusia itu hidup bermasyarakat, karena itu moralitas sosial menjadi landasan dalam kehidupan. Moralitas sosial perlu untuk menjamin manusia sebagai anggota masyarakat akan hidup dalam keadaan aman dan damai.

Peraturan masyarakat yang ditetapkan oleh kelompok ataupun otoritas yang berwenang perlu dipertahankan. Kelompok masyarakatlah yang paling berwenang dalam menggariskan kebenaran sosial. Karena itu peraturan moral bersifat kolektif. Dalam masyarakat ada persoalanpersoalan yang dianggap baik dan dianggap buruk. Masyarakat mempengaruhi tindak tanduk, sikap dan cara berpikir individu. Segala peraturan, larangan, dan pantangan yang ditetapkan oleh masyarakat adalah untuk kepentingan masyarakat dan bukannya individu. Individu hanya perlu patuh kepada peraturan yang ada dan jangan membantah. Memenuhi kehendak individu yang bertentangan dengan peraturan masyarakat adalah dianggap salah dan tidak bermoral.

Teori moralitas sosial menekankan bahwa segala peraturan, nilai, norma dan tatasusila yang diwujudkan dalam sebuah masyarakat itu adalah sesuatu yang disetujui bersama. Kewujudannya juga adalah untuk kebaikan, kepentingan dan keselamatan kelompok masyarakat tersebut. Contohnya, masyarakat menuntut nilai berdikari, hormat menghormati, 
kasih sayang, kebersihan, membantu, kerjasama, gotong royong, bersyukur, menghormati agama dan adat orang lain. Keadaan ini menjadikan keadaan kehidupan kita secara umum berlangsung damai. Masyarakat juga menolak sikap tamak, zalim, korupsi, kebohongan yang dapat mengganggu kesejahteraan hidup.

Semua nilai-nilai di atas pada intinya perlu disokong dan dipatuhi setiap individu sebagai bagian dari rasa tanggungjawab mereka sebagai pribadi maupun anggota masyarakat. Sebuah masyarakat yang aman dan damai adalah masyarakat yang senantiasa patuh dan mengamalkan peraturan-peraturan

kolektif

kehidupan. Sejauh kepentingan kelompok di tempatkan dalam posisi yang tinggi, di atas kepentingan individu, maka tidak akan ada konflik di antara individu yang tidak bisa diatasi. Jadi, teori ini menekankan pada kepatuhan pada autoriti. Sesuatu tindakan itu dianggap baik atau buruk, patut atau tidak patut, bermoral atau tidak bermoral jika selaras dengan nilai-nilai, norma-norma, dan undang-undang dalam masyarakat tersebut.
Kelemahan teori ini adalah karena terlalu memberikan keutamaan pada autoriti masyarakat (kelompok) maka kebebasan individu akan dikekang, sehingga tidak memberikan keleluasaan. Keadaan tersebut bisa melahirkan wujudnya individu-individu yang tidak kritis dan pengekor, mengikuti peraturanperaturan masyarakat yang telah digariskan. Padahal dalam kehidupan bermasyarakat diperlukan individuindividu kreatif yang bukan hanya menjadi penurut tetapi juga kritis menyikapi keadaan. Selain itu, karena kebenaran moral itu bersifat dinamis, berkembang dari waktu ke waktu, dari satu jaman kepada jaman yang lain, maka sangat mungkin ada sebagian nilai-nilai moral itu dapat berkembang dengan realitas kehidupan, sehingga masyarakat dapat "terkungkung" karena tidak ada yang berani menentang kebenaran moral yang sudah berlaku.

\section{Teori Kepribadian Mulia (Personality Virtue Theory)}

Teori ini bersumber dari pemikiran Aristoteles (384-322 SM). Menurut Aristoteles, etika dikaitkan pada kepribadian, sifat, perangai atau 
ciri-ciri perwatakan. Usaha pengembangan moral seharusnya mengarah pada pembentukan watak mulia dan terbaik, bukan kepatuhan kepada peraturan masyarakat. Melalui pengembangan watak mulia, nilai-nilai etis secara intrinsik lebih mudah tertanam. Aristoteles menggariskan sejumlah watak mulia manusia yang bermoral sesuai dengan jaman beliau hidup, seperti: Keadilan, kejujuran, persahabatan, amanah, bijaksana, murah hati, berani, dan sebagainya. Pada hari ini, sifat-sifat tersebut dapat kita elaborasi lebih jauh sesuai dengan perkembangan kehidupan. Berdasarkan teori ini, masalah yang lebih ditekankan adalah dimensi individu atau manusianya, dan bukan perbuatan yang dihasilkannya. Dalam pandangan Aristoteles, manusia perlu fokus kepada usaha membina kepribadian mulia, seperti yang dikatakannya sebagai etika virtue (Bailey 2010: 2).

Wujudnya pribadi mulia dengan sifat-sifat yang terpuji akan menciptakan keseimbangan dan kebahagiaan hidup. Sebagai suatu contoh, sifat jujur dan amanah dapat menjauhkan kita dari watak korupsi dan perbuatan mementingkan diri sendiri. Sementara sikap suka menolong orang lain akan membantu orang dalam memecahkan sebagian urusan hidupnya. Sifat tegas akan menjadikan kita lebih berprinsip dan dihormati, tidak mudah diombangambingkan oleh situasi. Sedangkan sikap bekerja keras membawa pada sifat kesungguhan, kecemerlangan dan keberhasilan. Dengan demikian, pribadi mulia akan mendorong pada perilaku bermoral. Sifat dasar manusia hakikatnya memiliki kecenderungan untuk menjadi lebih baik. Aristoteles sendiri sangat menekankan bahwa manusia mencapai kebahagiaan bukan dengan mengejar kesenangan dan menghindari perasaan sakit (seperti diajarkan kaum hedonis), atau dengan mengharapkan pemenuhan segala keinginan, melainkan melalui tindakan yang mengaktualisasikan potensi-potensi dalam dirinya. Dengan kata lain, kebahagiaan manusia dicapai melalui usaha pengembangan diri (Grcic 2013: 416).

Teori ini juga menjelaskan bahwa memiliki pribadi mulia bukanlah sesuatu yang bersifat alamiah, maksudnya manusia tidak dilahirkan dengan sifat baik atau jahat. 
Kepribadian yang ada pada manusia itu perlu diasuh, dipelajari dan dipraktekkan, baik itu melalui latihan serta pengamalan sehingga menjadi kebiasaan, tabiat, cara hidup dan menyenangkan diri sendiri. Seperti disampaikan Kees Bertens (1975: 162), pandangan ini menjelaskan bahwa untuk memperoleh keutamaan, kita mesti melakukan perbuatanperbuatan yang baik secara obyektif saja, artinya perbuatan-perbuatan yang oleh umum dianggap baik. Secara lambat laun suatu kebiasan yang baik dan terpuji itu akan terbentuk dalam diri kita, sehingga selanjutnya kita melakukan perbuatan-perbuatan baik tersebut berdasarkan keutamaan.

Selain itu, teori kepribadian mulia menyatakan bahwa untuk mencapai kemuliaan hidup, manusia perlu mengikuti “jalan tengah". Jalan tengah ialah tingkah laku yang sederhana, moderat, yaitu tidak berlebihan dan keterlaluan serta juga tidak terlalu kurang. Sebagai contoh (Bertens 1975: 163), dalam hal membelanjakan uang ada kemungkinan dua sikap ekstrim. Di satu pihak ada orang yang dapat mengeluarkan uang begitu banyak.
Sementara pada pihak lain ada sebagian orang yang cenderung pelit dan sukar mengeluarkan uang. Pihak yang pertama disebut sebagai pemboros, sedangkan yang kedua adalah kikir atau pelit. Kita dapat mengambil nilai keutamaan dalam membelanjakan uang ini dengan mengambil jalan tengah dari dua titik ekstrim tersebut. Nilai keutamaan ini ialah "kemurahan hati", yakni tidak terlalu boros dan tidak terlalu pelit. Dengan demikian, setiap keutamaan dapat menentukan jalan tengah antara dua titik ekstrem yang berlawanan. Keutamaan selalu merupakan pertengahan antara kelebihan dan kekurangan. Berdasarkan andaian tersebut sesuatu yang betul, benar, baik dan bermoral itu ialah perilaku yang mengikut kadar sederhana atau pertengahan.

Menurut Aristoteles, berdasarkan jenisnya, terdapat dua jenis kepribadian mulia, yakni kepribadian mulia intelektual dan kepribadian mulia moral. Kepribadian mulia intelektual ialah keutamaan melalui proses berpikir, yang menyempurnakan langsung rasio itu sendiri. Kepribadian jenis ini dapat dipelajari. Sementara kepribadian 
mulia moral diperoleh melalui latihan, praktek, dan kebiasaan dalam kehidupan sehari-hari (Bertens 2005: 243). Pandangan ini berhadapan dengan berbagai kritikan.

Aristoteles juga berpendapat dalam konsep etikanya bahwa tujuan akhir manusia adalah untuk mencari kebahagiaan (eudaimonia) dalam hidup. Menurut beliau, orang yang bahagia bukanlah seseorang yang kehidupannya dipenuhi dengan kenikmatan pasif, namun orang yang mampu melampaui seluruh aktifitas dan kecerdasan yang merupakan ciri dari manusia. Kebahagiaan bukanlah sekedar kepuasan, namun kesehatan, bisa menggunakan fakultas-fakultas mental secara imajinatif dan produktif, dan dapat menjalin hubungan personal, professional, dan publik yang baik (Graham 2015: 77).

Namun demikian, terlepas dari berbagai kelebihan pandangan Aristoteles, teori ini mendapatkan sejumlah kritik tajam. Di antaranya ialah: Pertama, teori ini lupa bahwa ukuran kebahagiaan untuk setiap manusia tidaklah sama. Antara satu individu dengan yang lain berbeda. Bagi sebagian individu, kebahagiaan adalah jika ia mempunyai kekayaan yang banyak. Sedangkan bagi yang lain jika ia merasa dirinya sehat. Sebagian lagi yang lain merasa bahagia jika bisa bersedekah. Ada yang bahagia kalau bisa menang dalam judi. Dengan demikian, kebahagiaan sesungguhnya bersifat relatif.

Kedua, kepribadian mulia mungkin juga dapat terjadi secara palsu dan pura-pura. Banyak orang yang berpribadi mulia di depan umum karena peraturan. Misalnya ada orang yang tidak melanggar peraturan dalam urusan di kantor, jujur dalam urusan kantor, tetapi melanggar peraturan ketika melintas di jalan raya. Dalam satu situasi mereka taat, tetapi dalam situasi lain mereka melanggar. Dengan kata lain, kepribadian mulia pada taraf tertentu mencetuskan hipokrisi. Ketiga, kepribadian mulia menurut Aristoteles bukanlah watak dan kemampuan yang bersifat alamiah. Argumen ini bertentangan dengan ajaran agama, di mana semua nabi memiliki akhlak mulia secara alamiah, sejak dilahirkan. Maksudnya, banyak perilaku baik atau buruk tidak dipelajari tetapi diperoleh melalui contoh keteladanan. Keempat, menyangkut konsep "jalan tengah", 
apakah setiap keutamaan itu selalu merupakan jalan tengah antara "kurang" dan "terlalu banyak". Hal ini tidak dapat dipraktekkan pada semua persoalan. Apalagi di jaman sekarang yang serba kompleks.

Meskipun demikian, terlepas dari segala kelebihan dan kekurangan, teori ini dapat menjadi panduan kita dalam mewujudkan kehidupan bersama yang damai dalam masyarakat. Adanya kemuliaan pribadi pada individu diharapkan mendorong wujudnya prinsip-prinsip kebaikan yang dijunjung secara kolektif serta memberi ruang bagi terbentuknya watak-watak terpuji.

\section{Teori Teleologi (Teleological} Theory)

Istilah teleologi berasal dari Bahasa Yunani, "telos", yang berarti tujuan. Teori ini menyatakan bahwa baik atau buruknya suatu perbuatan itu tergantung pada tujuan yang dicapainya. Suatu perbuatan yang memang bermaksud baik, tetapi tidak menghasilkan sesuatu yang bermakna, menurut aliran ini tidak pantas disebut baik (Bertens 2000: 67). Berlaku jujur, bijaksana, komited pada janji, ikhlas, menghormati orang yang lebih tua, adalah baik, karena hasil dari perbuatan tersebut adalah baik. Bukan karena sifat-sifat interen dari perbuatan tersebut. Begitu juga dengan perilaku berbohong, sombong, melanggar hak orang lain, menipu masyarakat, adalah buruk, karena apa yang dihasilkan dari perbuatan tersebut adalah buruk. Dengan demikian, penilaian terhadap sesuatu perilaku atau tindakan itu, apakah itu bermoral atau tidak bermoral adalah berdasarkan pada akibat yang ditimbulkan dari perbuatan tersebut. Jika perbuatan tersebut memberi akibat baik, maka perbuatan tersebut dianggap bermoral dan kalau perbuatan tersebut meninggalkan akibat yang buruk maka perbuatan tersebut dianggap sebagai tidak bermoral. Jadi sekali lagi, teori ini mementingkan dampak dari suatu perbuatan. Dengan kata lain, sebelum seseorang itu melakukan sesuatu tindakan atau perbuatan, maka ia perlu memikirkan terlebih dahulu dampak apa yang ditimbulkan, baik atau buruk. Kita dapat meneruskan perbuatan sekiranya itu berdampak baik, sebaliknya tidak akan melakukan sesuatu perbuatan sekiranya berdampak buruk. Dalam 
prakteknya, teori ini menekankan pada individu untuk mempertimbangkan konsekwensi dari perilakunya (Baumane-Vitolina, Cals, Sumilo 2016: 110). Bagaimanapun juga setiap perilaku akan membawa konsekwensikonsekwensinya sendiri. Tanpa adanya pertimbangan yang matang maka individu akan jatuh pada situasi yang tidak diinginkan.

Di kalangan para ahli, teori ini kemudian mencetuskan perdebatan. Muncul suatu pertanyaan, tentang siapakah yang lebih utama, apakah individu atau masyarakat, yang harus menerima manfaat dari akibat baik sesuatu perbuatan? Selanjutnya, timbul pula persoalan tentang apa yang dikatakan baik dan jahat? Perdebatan ini, telah memunculkan aliran Utilitarianisme dan Egoisme. Meskipun demikian, kedua aliran ini menekankan pada asumsi dasar yang sama, bahwa perilaku dan tindakan manusia haruslah didasarkan pada akibat atau dampak tindakan yang dapat membawa kebaikan atau keburukan.

\subsection{Utilitarianisme}

Aliran utilitarian dicetuskan oleh filosof Inggris, yakni Jeremy Bentham (1748-1832) dan John Stuart Mill (1806-1873). Kata "utility" bermakna "berguna" atau "kegunaan". Menurut teori ini, suatu perbuatan adalah baik jika membawa manfaat pada masyarakat secara keseluruhan atau banyak orang, dan bukan pada satu atau dua orang saja. Kriteria untuk menentukan baik buruknya suatu perbuatan adalah, the greatest happiness of the greatest number, yakni kebahagiaan terbesar dari jumlah orang terbesar. Jadi perbuatan yang mengakibatkan orang banyak bahagia adalah perbuatan terbaik (Bertens 2000: 66). Kenapa kita harus berlaku jujur dan tidak melakukan korupsi? Kaum utilitarian menjawab, karena dengan berperilaku jujur maka pembangunan akan berjalan baik, sehingga kualitas kesejahteraan masyarakat luas meningkat. Ini berarti kebahagiaan bagi sebagian besar orang. Dengan demikian, doktrin utilitarianisme mempunyai watak yang sepenuhnya bersifat kuantitatif, di mana satu-satunya tolok ukur perbedaan adalah quantum kebahagiaan yang ditimbulkan oleh 
tindakan yang berbeda-beda (Schmandt 2002: 445).

Persoalan individu tidak dipentingkan dalam aliran ini, malah individu perlu berkorban untuk kesenangan manusia terbanyak. Dari penjelasan di atas, dapat dipahami bahwa aliran utilitarianisme sangat menekankan pentingnya dampak atau konsekwensi dari suatu perbuatan dalam menilai baik dan buruknya. Jika suatu perbuatan mengakibatkan manfaat paling besar, dalam arti memajukan kesejahteraan, kebahagiaan, serta kemakmuran bagi orang banyak maka itu adalah perbuatan baik. Namun, jika sebaliknya yang terjadi maka itu adalah perbuatan buruk. Konsekwensi di sini amat dipentingkan, karena menentukan seluruh kualitas moralnya. Dari segi ini, aliran utilitarianisme seringkali disebut sebagai, "konsekuensialisme" (Bertens 2000: 67).

Pada tahap ini, aliran utilitarian seringkali dianggap membuka peluang lahirnya tindakan menghalalkan segala cara (ends always justify the means), di mana orang bertindak dengan cara-cara yang jahat agar tujuannya tercapai.
Suatu perbuatan yang bertujuan baik tidak boleh dilakukan dengan caracara yang tidak dapat dibenarkan secara moral. Kritikan lain terhadap teori utilitarian ialah, dapat menimbulkan konflik keadilan, di mana tindakan-tindakan yang diambil seseorang tidak menjamin berlakunya keadilan bagi hak setiap individu. Walaupun kepentingan masyarakat lebih utama, tetapi perilaku bermoral mestilah juga menghormati hak-hak mutlak individu. Kita bisa melihat contoh bagaimana tindakan yang diambil sebagian pemimpinpemimpin politik yang atas nama masyarakat luas (terbanyak) meraih ambisinya mengobarkan perang dan kemudian membawa dampak penderitaan pada sebagian orang. Contoh lain misalnya, pembunuhan besar-besaran terhadap kelompokkelompok kriminal, seperti penembakan misterius di tahun 1980an jaman Orde Baru, yang melampaui hak-hak sebagian orang meskipun tujuannya untuk membuat masyarakat Indonesia secara luas aman. 


\subsection{Egoisme}

Aliran egoisme merupakan cabang dari Teori Teleologi. Tokoh pencetus teori ini adalah Friedrich Wilhelm Nietzsche (1844-1900). Nietzsche merupakan tokoh filsafat yang yang menentang kecenderungan moral masyarakat yang mengaitkan autoriti agama dan Tuhan. Menurut beliau, jika Tuhan dan daya supernatural disingkirkan dari pikiran manusia, maka seluruh fondasi nilai-nilai moral tradisional juga runtuh (Graham 2015: 38). Nietzsche menentang pandangan umum yang berlaku ketika itu, di mana moral dikaitkan dengan pengorbanan diri, suara batin, serta konsep pahala dan dosa. Nietzche memandang bahwa pengkaitan moral dengan dimensi spiritual seperti itu hanya akan mengkerdilkan manusia serta melahirkan mentalitas moral "budak" yang merendahkan martabat manusia.

Padahal, menurut beliau, moral mestilah dikaitkan dengan pemeliharaan diri, kepentingan diri, peningkatan martabat serta tekad individu untuk unggul dalam kehidupan. Manusia sudah sepatutnya didorong untuk memilih unsur kehidupan yang memberikan kesempatan pada hasrat untuk mewujudkan ego individu pada tataran yang lebih tinggi sehingga menjadi Ubermensch (manusia unggul). Manusia unggul atau super adalah manusia yang kuat, berani, berbudi luhur, berbudaya, estetik, bebas, yang tidak dihadang belas kasih dengan yang lemah, dan yang seperlunya bertindak kejam (Franz Magnis-Suseno 1997: 198).

Menurut Nietzsche, secara esensial setiap tindakan manusia didorong oleh "kehendak untuk berkuasa". Adapun yang dimaksud Nietzsche sebagai "kehendak untuk berkuasa" adalah hasrat untuk menang dalam pertarungan yang merupakan kondisi esensial manusia. Karena itu, filsafat pemikirannya digolongkan sebagai egoisme (Graham 2015: 41). Dalam kaitan ini, beliau menentang segala peraturan mutlak dari autoriti. Peraturan haruslah bersifat individualistik, membelakangkan semangat kemasyarakatan, mengarahkan individu agar lebih kuat, cakap dan berkuasa. Prinsip utama aliran egoisme adalah, bahwa sebagai agen moral, individu bertanggungjawab 
memajukan diri dengan sebanyak mungkin kebaikan.

Kebijaksanaan mementingkan

diri dan mengutamakan diri merupakan satu tindakan moral yang betul, benar, mulia dan terpuji. Dalam pandangan Nietzsche, sifat-sifat seperti itu akan membebaskan individu dari belenggu-belenggu psikis yang tidak perlu, yang menjerumuskan manusia pada ketakutan dan surutnya semangat hidup. Jadi, dalam konteks kehidupan, menurut aliran ini nilai baik dan bermoral adalah nilai yang dapat memberi keuntungan pada diri, dan sebaliknya nilai buruk (tidak bermoral) jika sesuatu itu merugikan diri sendiri. Teori ini jelas bertentangan dengan teori kemoralan sosial sehingga menganggap kemoralan sosial sebagai "kemoralan hamba" dan manusia tidaklah sepantasnya menjadi hamba.

Pandangan aliran ini, dalam prakteknya diikuti sebagian pemimpin-pemimpin dunia yang pada akhirnya jatuh juga dari kekuasaan. Sebagai contoh kita bisa melihat tokoh-tokoh seperti: Stalin, Lenin, Saddam Hussein, Hitler, Syah Reza Pahlevi, Muammar Gaddafi, dan lain-lain, yang dengan penuh keegoisan mengumbar nafsu berkuasa dengan melakukan petualangan politik yang mengakibatkan kerugian pada sebagian besar rakyat. Mereka akhirnya tumbang juga dari kekuasaan. Dengan demikian, aliran egoisme sesungguhnya bertentangan dengan dimensi keadilan, kesetaraan, demokrasi dan mendorong manusia untuk bertindak zalim.

Secara teoritik, terdapat beberapa faktor yang menyuburkan munculnya aliran egoisme ini, yakni: Pertama, pengaruh lingkungan sosial. Banyak perilaku dan sifat-sifat manusia dihasilkan karena lingkungan sosial. Di antara perilaku satu individu dan individu lain tidak ada yang sama persis karena perbedaan lingkungan sosial mereka. Kedua, karena adanya sikap mempertahankan diri (ego), dalam arti wujudnya perasaan mengagumi diri sendiri. Dorongan tersebut semata-mata karena manusia berusaha untuk eksis dan saling mengungguli. Ketiga, adanya motif peribadi yang kekal, di mana manusia dalam berhubungan dengan orang lain selalu terpikir untuk kebaikan diri 
sendiri. Kepentingan yang demi kebaikan orang lain akan ditempuh sekiranya berkaitan dengan kebaikannya sendiri.

Kelemahan lain teori ini adalah, tidak memperhatikan sifat-sifat manusia yang beragama, serta kecenderungan naluriah spiritual yang dimiliki. Di mana tidak semua niat baik perbuatan individu sematamata bermotifkan kepentingan pribadi semata-mata. Padahal ada kecenderungan dalam diri manusia untuk bekerjasama, saling menolong, berbakti, toleran, sifat haru, mengasihi satu sama lain secara tulus. Selain itu, teori egoisme secara mentah-mentah menolak ajaran agama dan mengingkari prinsipprinsip moralitas agama. Seolah-olah individu bisa memecahkan sendiri semua urusannya tanpa bantuan orang lain, serta tanpa bimbingan kebenaran dari Tuhan.

\section{Teori Deontologi (Deontological}

\section{Theory)}

Istilah deontologi berasal dari perkataan Yunani, “deon”, yang berarti, "kewajiban" atau "sesuatu yang diwajibkan". Tokoh teori deontologi adalah Immanuel Kant
(1724-1804). Dalam teori ini yang menjadi dasar baik dan buruknya suatu perilaku itu adalah kewajiban. Suatu perbuatan itu baik, dan karena itu kita wajib melakukannya. Sementara perbuatan itu buruk, maka dilarang bagi kita. Teori ini menegaskan baik atau buruknya suatu perilaku itu tidak dinilai berdasarkan dampak yang ditimbulkannya, tetapi kewajiban. Sebagai contoh, kenapa kita harus berlaku jujur, adil, ikhlas, amanah, tidak menyakiti orang lain, karena itu adalah kewajiban. Begitu juga kenapa kita dilarang mencuri, korupsi, iri hati, karena hal tersebut dilarang dalam semua ajaran agama. Prinsip deontologi menyatakan, konsekwensi yang lahir setelah perbuatan itu dilakukan, adalah persoalan lain dan tidak boleh menjadi pertimbangan.

Perbuatan tidak pernah menjadi baik karena hasilnya baik, melainkan hanya karena wajib dilakukan. Karena itu, bisa dimengerti bahwa deontologi selalu menekankan bahwa perbuatan tidak dihalalkan karena tujuannya. Meskipun suatu perbuatan itu tujuannya baik, namun cara yang ditempuh salah maka tetap tidak bisa 
dianggap baik. Contoh misalnya, ada mahasiswa yang bertujuan untuk memperoleh nilai indeks prestasi yang tinggi, tetapi ketika dia ujian melakukan segala cara agar dapat nilai yang baik, termasuk dengan cara menyontek dan sebagainya. Maka perilaku semacam itu tetap tidak bisa dianggap baik. Jadi teori ini sangat bertolak belakang dengan teori teleologis yang kita bahas sebelumnya.

Secara substansial, aliran ini berpandangan bahwa perilaku bermoral itu mesti melibatkan kesadaran diri pelaku, yakni menekankan sifat perilaku manusia. Manusia dikatakan melakukan sesuatu itu tidaklah semata-mata karena tindakan tersebut dipikirkan baik atau buruk, bukan pula karena adanya sesuatu dampak perbuatan tersebut, bukan pula perbuatan tersebut akan membawa dampak bagi sebanyak mungkin orang, tetapi kita melakukan perbuatan tersebut karena nilai perbuatan tersebut (Dierksmeier 2013: 3). Jadi penentuan nilai baik, betul, wajar dan bermoral sesuatu tindakan atau perbuatan itu karena ciri-ciri atau sifatnya sendiri. Sifat perilaku dan ciri-ciri perilaku itu sendiri yang menentukan apakah suatu tindakan itu bermoral atau tidak. Dalam kaitan ini, ada beberapa bentuk teori deontologi, yakni: Deontologi tindakan, seperti eksistensialisme (etika situasi) dan deontologi peraturan seperti, Prinsip Kewajiban. Deontologi peraturan menyatakan bahwa pertimbangan moral diukur bergantung pada standard yang berlaku dan bukan karena kenikmatan (kesenangan) atau kesengsaraan. Tindakan yang sesuai dengan peraturan dianggap bermoral. Sementara deontologi tindakan berpendapat bahwa bermoral atau tidaknya suatu perilaku itu bergantung pada cara kita melaksanakan tanggungjawab pada orang lain. Adapun yang termasuk bagian dari deontologi tindakan adalah teori eksistensialisme.

\subsection{Teori Eksistensialisme}

Teori ini bersumber dari pemikiran Soren Kierkegaard (18131855), Albert Camus (1913-1960) dan Jean Paul Sartre (1905-1980). Aliran ini muncul setelah Perang Dunia Kedua. Salah pandangan eksistensialis berasal dari gagasan Kierkegaard tentang tiga gaya hidup 
yang bersifat estetis, etis, dan religious, yang bertransformasi menemukan pijakan hidup, yakni bagaimana kita harus mengisi kehidupan ini? Aliran Eksistensialisme menekankan kepentingan individu untuk memenuhi kehendak pribadi. Manusia bebas dan tidak terikat dalam menentukan pilihan-pilihan dalam kehidupan mereka. Manusia juga bertanggungjawab dengan pilihan dan tindakan yang dilakukannya. Aliran ini menolak ideide, norma-norma, peraturan dan kekuasaan yang datang dari luar diri manusia, karena manusialah yang lebih berhak dan pantas menentukan dirinya sendiri.

Jadi manusia bertanggungjawab atas dirinya sendiri untuk menetapkan tujuan dan membuat keputusan atau pilihan yang bebas dari norma-norma dan peraturan masyarakat. Konsep manusia berdasarkan aliran ini adalah bebas, tidak ada ikatan, menentukan baik atau buruk untuk dirinya sendiri, serta mencorakkan kehidupannya sendiri. Pada segi ini tidak ada satu hal pun yang dominan menentukan pilihan hidup kita, karena kita bebas, dan karenanya juga tidak ada satu pun yang bisa menjelaskan atau menjustifikasi siapakah sesungguhnya diri kita. Kesadaran mengenai kondisi tanpa pijakan atau dasar inilah yang disebut Albert Camus sebagai, "absurd".

Menurut Sartre, manusia wujud dahulu sebelum fungsinya ditetapkan, yang berarti kewujudan manusia mendahului esensinya hidupnya. Dengan kata lain, manusia wujud dahulu sebelum tujuan hidupnya ditentukan. Sesudah manusia hidup, barulah dia menentukan corak kehidupannya. Dalam pandangan eksistensialis kondisi manusia merupakan kebebasan sehingga menuntut tanggungjawab, yang tiada henti-hentinya pada kita, agar memilih nilai kita dan berkomitmen dengan nilai tersebut. Inti dari eksistensialisme adalah kebebasan radikal (Graham 2015: 132). Aliran ini jelas bertentangan dengan ajaran agama dan meniadakan kewujudan Tuhan yang menciptakan manusia. Sartre menegaskan, bahwa oleh karena tidak wujudnya Tuhan, berarti segala-galanya diizinkan, maka tidak ada hukuman Tuhan atau nilai agama, dan nilai obyektif disediakan untuk diikuti manusia. 
Tiada nilai moral yang tetap yang menjadi pegangan. Nilai-nilai moral senantiasa berubah mengikuti tanggapan dan tafsiran manusia serta keperluan dan situasi masanya. Golongan eksistensialis menitikberatkan kebebasan memilih dalam situasi terkini. Apakah kita adalah pencipta nilai? Sartre menjawab, ya. Kita adalah pencipta nilai, dalam arti "kita" sebagai bagian dari komunitas, etnik, ras, kultur di mana kita hidup. Dengan demikian sesuatu itu bisa disebut nilai dan bernilai ataupun tidak bernilai bergantung pada konteks. Jika nilai dibebaskan dari konteks, hal tersebut tidak masuk akal, tidak akan menjadi nilai. Karena itu, filsafat nilai paham eksistensialisme seringkali disebut sebagai "relativisme".

\subsection{Teori} Prinsip

\section{Kewajiban}

Teori ini dipelopori oleh Immanuel Kant (1724-1804), salah seorang tokoh filsafat Jerman yang terkenal. Beliau merupakan ahli filsafat moral yang terkenal sepanjang masa dan memberikan pengaruh besar pada pemikiran modern. Melalui pemikiran-pemikirannya beliau memberikan argumen tentang karakter fundamental dan rasional dari pemikiran dan tindakan moral. Kant mencetuskan Prinsip Kewajiban (principle of duty) yang bermaksud tanggungjawab perlu dilaksanakan semata-mata karena perbuatan tersebut adalah suatu tanggungjawab. Menurut Immanuel Kant, suatu perbuatan adalah baik jika dilakukan atau harus dilakukan karena kewajiban. Selanjutnya ia menyatakan, suatu perbuatan adalah baik jika dilakukan berdasarkan "imperatif kategoris".

Imperatif kategoris mewajibkan kita begitu saja, tidak tergantung pada syarat apapun. Misalnya uang yang telah dipinjam harus dikembalikan. Keharusan itu berlaku begitu saja tanpa syarat. Bukan karena kita takut akan dilaporkan ke polisi, terkena denda, atau dimarahi peminjamnya. Bukan karena hal-hal tersebut, melainkan seharusnya dikembalikan. Tanpa syarat apapun (Bertens 2000: 70). Teori moral yang dikemukakan secara mendalam oleh Kant ini akhirnya melahirkan etika Kant (Kant's ethics) atau etika Kantian (Kantian ethics). 
Kant banyak memperjuangkan kebebasan manusia, harkat dan martabat manusia, serta pandangan bahwa kewajiban moral bukan diperoleh dari Tuhan; atau bukan dari otoritas manusia dan masyarakat; atau dari kegemaran dan keperluan agenagen manusia tetapi dari proses berpikir. Hal ini sejajar dengan pengertian deontologi yang berasal dari kata "deon" dalam Bahasa Yunani yang bermakna "yang diharuskan atau diwajibkan".

'Teori etika ini menyatakan bahwa nilai moral suatu tindakan tidak boleh dinilai pada dampaknya (hasil atau kebaikan yang akan diperoleh), karena kesudahannya tidak jelas dan tidak dapat ditentukan pada saat tindakan tersebut dilakukan.

Nilai prinsip bermoral sesuatu tindakan itu bergantung kepada niat seseorang itu sebelum ia membuat keputusan atau melakukan suatu tindakan. Dampak atau akibat-akibat dari tindakan kita sebenarnya tidak berada di bawah kontrol kita. Sementara motif atau niatlah yang ada di bawah kontrol kita, dan karena itu kita harus bertanggungjawab secara moral atas motif kita untuk membuat kebaikan atau keburukan.
Seperti dicontohkan oleh Gordon

Graham (2015: 147) berikut:

...ada seseorang yang bekerja untuk lembaga amal internasional. Dia mengumpulkan uang dan mengorganisasi penyaluran obatobatan bagi orang-orang yang tinggal di kamp pengungsian. Di saat terjadi bencana besar dia bekerja dan berupaya keras untuk mengumpulkan uang dan mengumpulkan sejumlah besar obat-obatan yang sangat diperlukan. Namun akibat suatu kesalahan yang bukan diperbuat olehnya, gudang penyimpanan mengalami masalah sehingga stok obat-obatan terkontaminasi. Sayangnya, mereka tidak mengetahui kondisi ini sehingga kemudian tingkat kematian di kamp pengungsian jauh melebihi sebelum obat-obatan tersebut tiba. Ini tentu saja merupakan sebuah tragedi besar. Namun meski pekerja lembaga amal tersebut merasa sangat bersalah, dia sebenarnya bukan pihak yang bertanggungjawab atas kejadian ini. Kesalahan utama adalah pada 'nasib buruk' atau 'hal-hal buruk lainnya...

Dalam pandangan Immanuel Kant, niat dan upaya pekerja amal tersebut akan "tetap mengkilap seperti permata, seperti sebuah benda yang memiliki makna penuh bagi dirinya sendiri”. Menurut Kant, sifatsifat seperti kebaikan, keberanian, ketabahan, kepandaian, kekayaan 
serta kehormatan adalah diingini semua orang. Namun semua hal tersebut tidak dapat dianggap baik atau buruk tanpa syarat. Sesuatu itu baik, buruk, bermoral atau tidak, bergantung pada tekad baik atau buruk yang diniatkan oleh individu yang bersangkutan. Motif tunggal tekad baik adalah melaksanakan kewajiban (Walschots 2015: 103104). Mengamalkan kewajiban haruslah dengan tekad baik secara batin. Jadi manusia yang baik dari segi moral ialah manusia yang senantiasa bertindak atas dasar kewajiban atau karena peraturan. Berperilaku yang semata-mata dilandasi oleh kecenderungan alamiah saja dianggap tidak rasional dan tidak melibatkan nalar pikir yang bebas. Kehendak baik adalah kehendak rasional murni.

Dengan hidup menurut hukum moral yang rasional manusia tidak menyerahkan diri pada sesuatu yang asing bagi dirinya (heteronom).

Di sinilah manusia dapat menemukan "otonomi kehendak", yang serentak juga menemukan kebebasannya. Dalam konteks perbuatan manusia, Kant menolak segala bentuk kewujudan dan campur tangan Tuhan.
Dalam pandangan beliau, manusia perlu berperilaku mengikuti peraturan universal. Pertimbangan moral, apakah itu benar atau salah bergantung pada kepatuhan peraturan universal, yang mencakup prinsipprinsip: Kebebasan, keadilan, kebijaksanaan, pilihan yang tepat. Dengan adanya kebebasan dan keadilan kita boleh menggunakan kebijaksanaan untuk membuat pilihan tindakan yang bersifat universal. Suatu prinsip bertindak hanyalah benar apabila dapat diuniversalisasikan, yakni dapat diberlakukan pada siapa saja dan komunitas mana saja. Penguniversalan ini ciri hakiki kewajiban moral (Franz MagnisSuseno 1997: 148).

Pada kenyataannya, teori Prinsip Kewajiban ini mengundang berbagai kritik. Salah satunya adalah, pandangan Kant yang menyatakan bahwa kita perlu bertindak mengikuti "motif kewajiban" dan bukan mengikuti "kecenderungan". Bagaimanapun hal ini mengingkari kenyataan, di mana dalam kehidupan ini banyak perilaku bermoral kita yang dilakukan dengan sebab kewajiban, seperti: membayar pajak, 
taat berlalu lintas, bersih-bersih lingkungan, dan sebagainya. Namun, banyak juga perilaku moral kita yang dilakukan karena kecenderungan alamiah untuk melakukan tindakan tersebut, di mana kita mendapat kepuasan dari tindakan seperti itu. Perilaku ini justru lebih memberi kesan mendalam, karena membawa kepuasan inheren dalam diri kita, yang bisa jadi karena dorongan agama. Pemikiran Kant yang sepenuhnya bertitik tolak dari nilai sekularisme tentu tidak akan ketemu dengan nalar moral seperti itu.

\section{Kesimpulan}

Berdasarkan penjelasan yang disampaikan di atas dapat dikemukakan bahwa etika adalah suatu kajian ilmiah tentang perilaku manusia dalam masyarakat, yakni suatu bidang yang mendefenisikan perilaku manusia sebagai benar atau salah, baik atau buruk, patut atau tidak patut. Etika menegaskan prinsip-prinsip perilaku yang perlu ditempuh individu agar bersesuaian dengan kebajikan yang diterima. Kesadaran akan nilai-nilai tersebut perlu dipupuk secara terus menerus. Dalam lingkup kehidupan sehari-hari, kita mengenal adanya berbagai macam pedoman etika atau kode etik, mulai dari etika organisasi, lembagalembaga pemerintah dan swasta, korporasi, sekolah, pesantren, serta profesi, yang menjadi pemandu bagi perilaku individu, atau kelompok dalam organisasi atau profesi pekerjaan.

Sejauh yang kita kenal ada beberapa teori etika, yakni: Pertama, teori moralitas sosial (sosial morality theory). Teori ini menyatakan bahwa manusia hidup bermasyarakat, karena itu kelompok masyarakatlah yang paling berwenang dalam menggariskan kebenaran sosial. Masyarakat mempengaruhi tindak tanduk, sikap dan cara berpikir individu. Sesuatu tindakan itu dianggap baik atau buruk, patut atau tidak patut, bermoral atau tidak bermoral jika selaras dengan nilainilai, norma-norma, dan undangundang dalam masyarakat tersebut.

Kedua, adalah, teori kepribadian mulia (personality virtue theory). Teori ini bersumber dari pemikiran Aristoteles (384-322 SM). Menurut teori ini, usaha pengembangan moral seharusnya mengarah pada pembentukan watak mulia dan terbaik, 
bukan kepatuhan kepada peraturan masyarakat. Berdasarkan teori ini, masalah yang lebih ditekankan adalah dimensi individu atau manusianya, dan bukan perbuatan yang dihasilkannya. Dalam pandangan Aristoteles, manusia perlu fokus kepada usaha membina kepribadian mulia, seperti yang dikatakannya sebagai etika virtue.

Ketiga, teori teleologi. Teori ini menyatakan bahwa baik atau buruknya suatu perbuatan itu tergantung pada tujuan yang dicapainya. Suatu perbuatan yang memang bermaksud baik, tetapi tidak menghasilkan sesuatu yang bermakna, menurut aliran ini tidak pantas disebut baik. Jika perbuatan tersebut memberi akibat baik, maka perbuatan tersebut dianggap bermoral dan kalau perbuatan tersebut meninggalkan akibat yang buruk maka perbuatan tersebut dianggap sebagai tidak bermoral. Teori ini mementingkan dampak dari suatu perbuatan. Teori teleologi terbagi menjadi dua, yakni aliran Utilitarianisme dan Egoisme. Keempat adalah, teori deontologi. Teori ini menegaskan baik atau buruknya suatu perilaku itu tidak dinilai berdasarkan dampak yang ditimbulkannya, tetapi kewajiban. Perbuatan tidak pernah menjadi baik karena hasilnya baik, melainkan hanya karena wajib dilakukan. Jadi penentuan nilai baik, betul, wajar dan bermoral sesuatu tindakan atau perbuatan itu karena ciri-ciri atau sifatnya sendiri. Ada beberapa bentuk teori deontologi, yakni: Deontologi tindakan, seperti eksistensialisme (etika situasi) dan deontologi peraturan seperti, Prinsip Kewajiban.

\section{DAFTAR PUSTAKA}

Ahmad Amin. 1983. Etika (Ilmu Akhlak), Terj. KH. Farid Ma'ruf, Jakarta: Bulan Bintang.

Bailey, Olivia. 2010. "What Knowledge is Necessary for Virtue?", Journal of Ethics \& Sosial Philosophy, Vol. 4, No. 2 (February), p. 1-17.

Baumane-Vitola, Cals, Igo, Sumilo, Erika. 2016. "Is Ethics Rational? Teleological, Deontological and Virtue Ethics: Theories Reconciled in the Context of Traditional Economic Decision Making", Procedia Economics and Finance, Vol 39, p. 108-114.

Bertens, K. 1975. Sejarah Filsafat Yunani: Dari Thales Ke Aristoteles, Yogyakarta: Kanisius. 
Bertens, K. 2000. Pengantar Etika Bisnis, Yogyakarta: Kanisius.

Bertens, K. 2005. Etika, Jakarta: Gramedia.

Davis, Michael. 2014. "Professional Ethics without Moral Theory: A Practical Guide for the Preplexed Non-Philosopher", Journal of Applied Ethics and Philosophy, Vol. 6, No. 9, p. 19.

Dierksmeier, Claus. 2013. "Kant on Virtue", Journal Business Ethics, April, p. 1-8.

Franz Magnis-Suseno. 1997. 13 Tokoh Etika: Sejak Zaman Yunani Sampai Abad Ke 19, Yogyakarta: Kanisius.

Graham, Gordon. 2015. Teori-Teori Etika, Terj. Irfan M. Zakkie, Bandung: Nusa Media.

Grcic, Joseph. 2013. "Virtue Theory, Relativism and Survival", International Journal of Sosial Science and Humanity, Vol. 3, No. 4, Juli, p. 416-419.

Hamzah Ya'qub. 1983. Etika Islam, Bandung: Diponegoro.

Ljupco, Ristovski. 2017. "Morality and Ethics in Politics in the Contemporary Societies", Journal of Liberty and International Affairs, Vol. 2, No. 3, p. 83-93.

M. Amin Abdullah. 2002. Filsafat Etika Islam, Bandung: Mizan.
Palese, Emma. 2013. "Ethics without Morality, Morality without Ethics-Politics, Identity, Responsibility in Our Contemporary World", Open Journal of Philosophy, Vol. 3. No. 3, p. 366-371.

Schmandt, Henry J. 2002. Filsafat Politik: Kajian Historis Dari Zaman Yunani Kuno Sampai Zaman Modern, Terj. Ahmad Baidlowi \& Imam Baehaqi, Yogyakarta: Pustaka Pelajar.

Suikkanen, Jussi. 2009. "Consequentialism, Constrains and the Good Relation-to: A Reply to Marx Schroeder", Journal of Ethics \& Sosial Philosophy, March, p. 1-8.

Walschots, Michael H. 2015. Moral Sense Theory and the Development of Kant's Ethics, Thesis Doctor of Philosophy, The School of Graduate and Post Doctoral Studies The University of Western Ontario, Canada. 